\title{
Analysis on Constitution of Melfi and the Appellate Jurisdiction System of Swabian Sicily
}

\author{
Yuanyuan Chang ${ }^{1}$ Yan $\mathrm{He}^{1, *}$ \\ ${ }^{1}$ School of Public Affairs and Administration, University of Electronic Science and Technology of China, \\ Chengdu, Sichuan 611731, China \\ *Corresponding author. Email: hyspace0918@163.com
}

\begin{abstract}
Constitution of Melfi, also known as Liber Augustalis, formally established the appellate jurisdiction system of Swabian Sicily by statute law. The jurisdiction in the kingdom was shared by both judicial officials and administrative officials who wielded little judicial powers. The former kind included master justiciar, justiciar, judge and their courts while the latter refers to bailiff and chamberlain. There was a distinctive hierarchy and boundary of jurisdiction among them. Swabian Sicily's advanced appellate jurisdiction system was beneficial to maintaining judicial fairness while strengthening the kingship of Friedrich II and his successors.
\end{abstract}

Keywords: Constitution of Melfi, Master justiciar, Justiciar, Judge, Chamberlain, Bailiff, Appellate jurisdiction system.

\section{INTRODUCTION}

Friedrich II of the Hohenstaufen Dynasty established a relatively sophisticated appellate jurisdiction system in the Kingdom of Sicily based on the original judiciary of the Byzantine and Norman period by promulgating the Constitution of Melfi. Appeals could be lodged multiple times by the litigants through various approaches in Sicily at that time. This paper mainly focuses on analyzing relevant official positions and their jurisdiction limits from the text of the Constitution of Melfi [1] meanwhile evaluating the system given the historical background and several related materials.

\section{JUDICIAL DEPARTMENTS AND OFFICIAL POSITIONS WITH JUDICIAL POWER}

In the Kingdom of Sicily, subjects who exercised jurisdiction fell into three categories: master justiciar from Magna Curia, justiciar and judge. Courts containing those three were the backbone of the realm's judicial system.

Master justiciar ranked the highest among the nation's judicial officials, his status and potency in the judicial system equaled the king himself, the Magna Curia he worked for was the highest judicial organ in Kingdom of Sicily. The historical origin of the Magna Curia dates to the Norman period when Roger II had implemented his administrative system reform. Guglielmo II vested it with judicial function in 1172 and the king started to carry out daily judicial activities with the assistance of three master justiciars, making the Magna Curia a symbol of the king's court. During the reign of Friedrich II, the Magna Curia's status and judicial functions as the supreme court of the realm was officially affirmed by the Constitution of Melfi. It was capable of having Master justiciar and other staff, summoning witnesses and holding hearings ${ }^{1}$. On behalf of the king, the master justiciar exercised jurisdiction over people from all social classes and dealt with appeals from lower courts in Magna Curia. Sometimes, the King himself would adjudicate cases and the master justiciar presided over circuit courts occasionally ${ }^{2}$.

Based on the former administrative divisions in the Norman period, Friedrich II divided the realm of Sicily into 9 provincial jurisdictions named "giustizierato" (justiciarate), they were Abruzzo, Basilicata, Calabria, Capitanata, Principato e Terra Beneventana, Terra di Bari and Terra di Lavoro.

$\begin{array}{ll}\text { 1. } & \text { Const. I. } 40 \\ \text { 2. } & \text { Const. I. } 48\end{array}$ 
The borders of these justiciarates were roughly consistent with those of the administrative regions [2]. Justiciars were the Chief Judge of each corresponding justiciarate. They presided over the provincial court, exercised appellate jurisdiction and dealt with difficult and important cases within their justiciarates.

The predecessor of the title "justiciar" was an official position called " $\mu \varepsilon \gamma \alpha \lambda \mathrm{or} \kappa \rho \iota \tau \alpha \iota "$ in the Byzantine period which wielded administrative and judicial power [3]. It was in Roger II 's political reform that the position of justiciar was officially established and was called "justifator" or "justificarius" at that time [4]. In the beginning, they had unlimited authority within their jurisdiction and an extensive range of jurisdiction for first trials, which had been greatly restricted by the Constitution of Melfi during the reign of Friedrich II.

Judges and their courts were the most basic elements of the appeal system, and they processed most of the civil and criminal cases in the name of the king. Those courts were mostly located in the cities within the realm. Their jurisdiction was each city itself and the affiliated area ${ }^{3}$. The posts of judges must be held by native people who were familiar with local customs. There would be no more than five judges in each of the major cities such as Naples, Salerno and Capua, three in other cities $^{4}$.

Additionally, administrative officials like chamberlain and bailiff also exerted a small amount of jurisdiction as a complementary approach for the preview stated system for effective governance and respect for Norman tradition. Chamberlains served both administrative and judicial functions. They juggled with fiscal works, tax revenue and civil cases. Deducting from the Constitution of Melfi, bailiffs in Swabian Sicily undertook functions of public security administration ${ }^{5}$ and justice on the grass-roots level ${ }^{6}$. Their obligations included maintaining social order and attending trials held by local judges and justiciars. The office of bailiff in Swabian Sicily was similar to the Justice of the Peace in modern Britain. Among those five positions, only the bailiff was appointed by the chamberlain; the other four were directly appointed by the king himself and their salaries were paid by

\footnotetext{
3. Const. I. 73

4. Const. I. 74

5. Const. I. 42

6. Const. I. 41,60
}

the state treasury. Below are the detailed introductions of their jurisdictions.

\section{DIFFERENT POSITIONS AND THEIR JURISDICTION}

\subsection{Bailiff}

Extremely limited judicial jurisdiction, only had jurisdiction over certain civil cases concerning all real and personal cases about fiefs and feudal properties and minor criminal cases in which the guilty party would not be sentenced to death penalty or mutilation, such as theft ${ }^{7}$. Additionally, bailiffs didn't hold appellate jurisdiction.

\subsection{Judge}

Relatively broad jurisdiction, judges were in charge of the first trial of most cases and didn't have appellate jurisdiction.

\subsection{Chamberlain}

Relatively restricted jurisdiction, only focused on civil cases. In charge of first trial of certain types of cases: (1) Civil cases in which at least one of the parties was a castellan during their castellanship ${ }^{8}$. (2) Disputes about tribute (the rent paid by the officeholder of bailiff in return for the office, collected by collectors) between bailiffs and collectors $^{9}$. (3) Cases handed over, delayed or neglected by the bailiffs. As for appellate jurisdiction, the chamberlain had a higher level of trial than judges in civil cases and was entitled to judge a second trial for some of the cases from the judges. They could either uphold the verdict or change the original sentence made by judges. When holding a hearing about appellate cases, the local bailiffs should be present at the chamberlain's court. To avoid waste of judicial resources, the appellate cases conducted by chamberlains should be appealed directly to Magna Curia and master justiciar instead of provincial justiciars' $\operatorname{courts}^{10}$.

\subsection{Justiciar}

Justiciar was responsible for the first trial of some major and special cases within his justiciarate. His relatively narrow jurisdiction for first trials

\footnotetext{
7. Const. I. 65

8. Const. I. 92

9. Const. I. 60

10. Const. I. 60
} 
mainly had four types: (1) When a castellan was involved in criminal cases ${ }^{11}$. (2) Severe criminal cases where litigants may suffer the penalty of death or mutilation. (3) When the feudal court failed to deliver a valid judgement in the given 2 months' time. (4) Disputes about the great fiefs and lords' feudal properties ${ }^{12}$. Meanwhile, the justiciar had a broad appellate jurisdiction within his justiciarate as the chief provincial judicial officer. The justiciar was entitled to deal with all appellant cases from judges' courts and cases in which the bailiffs and chamberlains made defective first sentences and couldn't correct the mistakes they had made in two months. When the litigant was dissatisfied with the result of the first in-stance, he or she could appeal to the justiciar ${ }^{13}$.

\subsection{Master Justiciar and Magna Curia}

Entitled with absolute prior, jurisdiction thus had the prerogative of hearing any case at liberty and they had the power to demand the transfer of jurisdiction, even if the case was proceeding. Taking justiciar's first trial cases for example, it was expressly stipulated in the Constitution of Melfi, book II, Title 22 that if the Magna Curia demands jurisdiction of a case subjected to a justiciar's jurisdiction, the justiciar aforesaid must hand it over promptly and without any hesitation to the master justiciar. Meanwhile, the nature of the case and how far the process had gone must be explained to the master justiciar by the justiciar in a letter ${ }^{14}$. There were three types of major cases for which the first trial must be conducted by the king's court: (1) civil cases concerning great fiefs. (2) civil cases with cities and castles involved. (3) cases about the title of baron or count and their fiefs which must have been registered in the finance office of the barons ${ }^{15}$. Besides, mater justiciar and Magna Curia had superior appellate jurisdiction. All cases in the realm could be appealed to this level and had a chance to receive its final judgement. ("Figure 1")

\section{Appeal System}

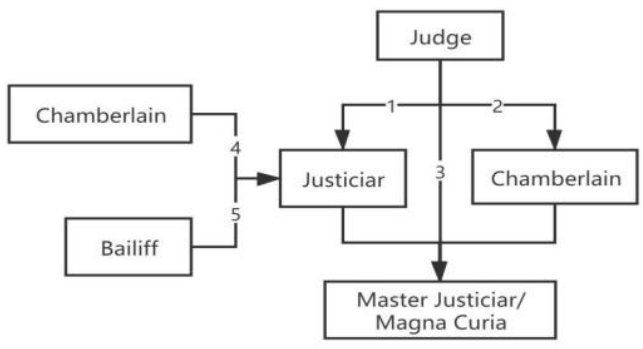

Figure 1 Five different approaches of appeal in Swabian Sicily.

\section{A BRIEF COMPARISON WITH THE ENGLISH COUNTERPART}

The Kingdom of England in the corresponding period established a similarly differential appellate jurisdiction system. However, it had several deficiencies compared to the system in Swabian Sicily. The secular courts in England entrenched three forms of supervision for lower courts like feudal courts and county courts on the king's behalf. Those three were royal afforecement, accedes ad curium and false judgment. The first two forms only had limited supervisory role and of applicable circumstances, only the third one, false judgement, could be regarded as an appellate procedure. It could act as a second trial, in which the king's court had discretionary power over cases and was thus able to change the existing effective judgement. In a word, the appeal system of England in the thirteenth and fourteenth centuries mentioned above was oversimplified. The litigant could only appeal once with the sole approach to the king's court [5]. As the king's court only had limited judicial resource, the appeal system in England could only offer limited judicial remedy. Compared to the fully fledged appeal system in the Kingdom of Sicily, the appeal system in the Kingdom of England lacked multiple appeal approaches, which may not have satisfied people's demands for justice. By comparison, it was clear that the appeal system in the Kingdom of Sicily was a more advanced system.

\section{CONCLUSION}

The higher courts in the Kingdom of Sicily supervised subordinate courts and rectified the defect of lower courts systematically via the appellate jurisdiction system mentioned above. By doing so, it prevented unjust, false, and erroneous convictions while offering effective judicial remedy. 
To some extent, this appellate jurisdiction system resolved social conflicts and disputes thereby safeguarded fairness and justice in judicial activities to some extent. The establishment of such a sophisticated appellate jurisdiction system served the following purposes: promoted nomocracy, weakened the judicial privileges of the Catholic church and feudal lords, also strengthened kingship and centralized power of the secular State as well. All those above made it possible for Swabian Sicily to become the first absolute monarchy state in Europe and had great influence on later reforms in Western Europe.

\section{AUTHORS' CONTRIBUTIONS}

Yuanyuan Chang is responsible for conceptualization, methodology, analysis, writing original draft, resources. Yan He is responsible for analysis, visualization, writing-review and editing.

\section{REFERENCES}

[1] Powell J M, The Liber Augustalis: Or, Constitutions of Melfi, Promulgated by the Emperer Frederick II for the Kingdom of Sicily in 1231, Syracuse University Press, 1971.

[2] Scrofani L, Administrative Divisions in Sicily from the Roman Empire to the Present: A Journey Through Strategic Functions, Local Development Perspectives and «Gattopardismo» in the Governance of the Territory, Bollettino della Società Geografica Italiana, 2016, 9(1-2): pp. 281-290.

[3] Cabrol F. J. Gay, L'Italie méridionale et l'empire byzantin depuis l'avènement de Basile Ier jusqu'à la prise de Bari par les Normands (867-1071).(Bibliothèque des Écoles françaises d'Athènes et de Rome. Fasc. 90.)(Book Review), Revue d'Histoire Ecclésiastique, 1905, 6: pp. 107.

[4] Jamison E, The Norman administration of Apulia and Capua: more especially under Roger II. and William I. 1127-1166, Papers of the British School at Rome, 1913, 6(6): pp. 211-481.

[5] Capua J V, Feudal and Royal Justice in Thirteenth-Century England: The Forms and the Impact of Royal Review, American Journal of Legal History, 1983, 27(1): pp. 5484. 